\title{
Geopolitical Configurations after the Former Yugoslavia and Kosovo Independence
}

\author{
Genc Mekaj ${ }^{1}$ \\ ${ }^{1}$ College ILIRIA \\ 75 Gazmend Zajmi Street, Prishtinë, 10000, Republika e Kosovës
}

DOI: $10.22178 /$ pos.65-7

JEL Classification: H54

Received 15.11.2020

Accepted 25.12.2020

Published online 31.12.2020

Corresponding Author:

gencmeka@hotmail.com

(C) 2020 The Author. This article

is licensed under a Creative Commons

Attribution 4.0 License @ (1)

\begin{abstract}
The disintegration of the former Yugoslavia marked the end of the armed conflicts, bringing the region's geopolitical configurations in which it lay. This article gives details the geopolitical designs following the breakup of the former Yugoslavia. It also provides details about foreign geopolitical influences and their interests in the region. In the vortex of the former Yugoslavia's disintegration, the most sensitive case in all framework is Kosovo's case. The problematic past between Albanians and Serbs poses a significant challenge. The Albanian factor in the Balkans is also a problem that brings general challenges in the region without solving it in the right way. In this article, we have tried to elaborate Kosovo Independence's case to bring stability and consolidation of security for the country and the region. We have tried to present that the former Yugoslavia countries should learn from the past and cooperate for a general future. Through cooperation and overcoming classical thinking to orient towards the end, it should bring peace and stability, especially for each country and the Balkan region.
\end{abstract}

Keywords: former Yugoslavia; Kosovo independence; geopolitics; Balkans; wars.

\section{INTRODUCTION}

The Balkan countries have always encountered difficulties in creating internal stability of living and functioning, being influenced by the external influences and resistances of the larger states' various interests. Conflicts of interest between the West and the East have led to instability in this region.

The various influences and impositions from the third factors conveyed throughout history have strongly influenced the economic, political life, and other areas of this region. Evidence of this is the Yugoslav federation which was a variety of changes in the Western Balkans.

There are different ideas and opinions on Yugoslavia's issue and its disintegration, which have been discussed and exposed differently and have brought various assessments and arguments. All the other attempts, reactions, ideas, views and perspectives on this issue could not stagnate or change the former Yugoslavia's disintegration.
The disintegration of the former Yugoslavia is compounded by a large number of internal and external factors. The former Yugoslavia filled with different ethnicities and denominations persecuted by ideological currents for centuries could not have a long life. Disintegration, changes and configurations in the region came about for many reasons: ethnic, national, political, historical, economic, military, geopolitical and geostrategic.

After the former Yugoslavia, the geopolitical configurations have been and still are followed by the numerous interests of foreign actors who in various forms are involved in these regions. The disintegration of the former Yugoslavia brought geopolitical configurations to the area, forming new states based on self-determination. Multiethnic states based on a system of democracy were also created.

Our treatment deals with the geopolitical processes and changes in the countries of the former Yugoslavia. After the former Yugoslavia's disintegration, the geopolitical configurations brought 
the Balkans new maps, new approaches, and new challenges.

We have divided our study into two parts. First, in the geopolitical configuration and emergence of new states after the disintegration of the former Yugoslavia. Also, the geopolitical and geostrategic influences and developments in this region accompanied by internal and external forces. The second; Kosovo's independence as a geopolitical configuration that occurred after the former Yugoslavia's disintegration. With the international community's support, Kosovo's independence has brought stability and security to the region. The principle of self-determination has been implemented. The long-standing deep-rooted problem between Serbs and Albanians of Kosovo has been mitigated.

\section{RESULTS AND DISCUSSION}

\section{Geopolitical configurations after the disintegration of the former Yugoslavia}

Influenced by non-Balkan factors in the post-Cold War period and the disintegration of the Yugoslav federation, the geopolitics of the Balkans began to rise based on [6]: 1) the defactorization of the principle of territorial integrity, a factor which prevailed for about a hundred years over this geospace, especially for multinational environments; 2) factoring the principle of self-determination of peoples.

With the end of the Cold War, the Balkans' problems and crises have been problematic for the region and Europe. All Balkan countries have issues with each other, some more and some less. The Balkans constitute the chain of neighbouring problems, especially in the ethnic case. The Balkans' general conflicts and crises are the product and result of a series of complex interactions of various factors such as; historical, ethnic, religious, political, economic, military that allude to deep ideological and geopolitical imperatives by external factors.

The processes and events that took place in Eastern Europe after the two significant events in the world. That of the fall of the Berlin Wall and the disintegration of the Soviet Union put the Yugoslav federation's dissolution irreversibly, giving an unstoppable impetus to the process which the interior had begun after Tito's death.
Regarding the impact of the dissolution of the Soviet Union, Alexander Dugin also states that: Geopolitically, the disintegration of the USSR signified an event of colossal importance, affecting the entire structure of the global geopolitical map [5]. So, this collapse affected and affected the geopolitical map of the region of the former Yugoslavia. The former Yugoslav federation's disintegration would bring about significant geopolitical changes and configurations in the Western Balkans.

The end of the bipolar world, which came with the fall of the Berlin wall, carried much more weight for ex-Yugoslavia than the new chance for change to the communist regimes. Put, at that very moment, two aspects of a lack of legitimacy hit Yugoslavia: one from within and one from the outside. The absence of any agreement on the shared state's future design was strengthened by the apparent loss of Yugoslavia's external legitimacy. The space the country had kept between the two "blocks" because of its successful non-aligned foreign policy, instantly disappeared, and Yugoslavia - until then supported by the blocks' existence dropped into the abyss created when they disappeared. The country's severe economic crisis, the war-oriented strategies of the political elites of former Yugoslavia, confusion in European and world politics vis-à-vis the Yugoslav crisis - were all additional pushes towards the point of no return [14].

In the disintegration of the former Yugoslavia, external and internal factors were directly and indirectly impacted. Circumstances, changes, and developments that gripped the world, such as the end of the Gulf War, Germany's unification, the fall of the Berlin Wall, and the Soviet Union's disintegration, show that ethnic stability and that of the Balkans as a whole was an illusion.

The primary and most essential factors in the Balkans' geopolitical configuration was the active involvement of the international aspect in this region in all forms and the military structure.

Geopolitically, the population of Yugoslavia, which had a multiethnic and multi-religious composition, was greatly influenced by external factors that had their roots in the 19th and 20th centuries, influences which had to do mainly with ethnic and religious affiliations. Structural diversity in many respects within Yugoslavia was the factor that worsened the sustainability of the latter. Also, the processes of self-determination by ethnicity and various national movements were influential factors within Yugoslavia. 
Two central communities in Yugoslavia threatened its existence: Albanians and Slavs. Within Yugoslavia, predominantly Slavic, lived Albanians who differed ethnically and religiously (including Bosniaks religiously) from other Yugoslavia peoples.

About 2 million Albanians lived in Kosovo. In Macedonia 400 thousand, and in Montenegro 55 thousand, as well as in Albania and Greece there were Albanians. Thus, the number of Albanians was a real danger to the Slavs within Yugoslavia. Albanians never felt comfortable as well as part of Yugoslavia which consisted of the majority Slavs. The conscience of a common fate, the will to live together, the whole feeling that compound the elements for a nation are the real foundation of its viability. All this never existed in that nation [8]. One of the critical factors of the wars in Yugoslavia's territory was Serbian nationalism, which impacted other regions' peoples.

The fragmentation of the Balkans, especially after the former Yugoslavia's disintegration, took place for many reasons; historical, economic, political, geopolitical, military, strategic-geostrategic. The breakdown of the former Yugoslavia was followed by changes in maps as well as geopolitical configurations. The number of states after the disintegration of Yugoslavia increased with the emergence of new forms. Some of them made the secession gently and some through conflicts such as; Croatia, Bosnia and Herzegovina and Kosovo.

The violent and bloody dissolution of the former Yugoslavia has influenced the region to create a new geopolitical reality and configuration.

Slovenia. Croatia and Slovenia were the first of six republics to vote for independence. Together, they planned their independent nation's departure on June 25, 1991 [13]. Slovenia's independence began as an economic clash and ended in a conflicting crash like the Ten-Day War. Slovenia's path was not very difficult; it was crossed only by a short conflict, which resulted in the country's independence.

Slovenia is the country with the highest income in the Balkan Peninsula, with a very prosperous and developed economy.

It is the first country in the region to join NATO. Slovenia is also a member of the EU.

Croatia. Unlike Slovenia, Croatia went through and experienced conflict during its secession from the Yugoslav federation. There were inter-ethnic clashes between Serbs and Croats in Croatia. Clashes between Serbs and Croats were numerous, causing both sides to fight each other with cruelty and cynicism, alluding that each side is right. Croats consider the conflict as an aggression against their independent Croatian state by Yugoslavia, emphasising Serbia. Simultaneously, Serbs have always called for the war in Croatia to be a civil war, covering political propaganda for the purposes and interests.

Croatia took a step towards securing national independence and seceded from Yugoslavia by holding a referendum in 1991 in which a high percentage of voters voted for Croatian independence. The Croatian Parliament passed legal laws on secession from the federation and demarcated borders, Croatia declared independence in 1991. Croatia is member of NATO as well as a member of the EU.

Macedonia (North Macedonia). Historically, Macedonia (North Macedonia) has been a centre where Greeks' interests and nationalist efforts, Serbs and Bulgarians are intertwined. Still, later Macedonia became an inseparable apple among its neighbours due to its declaration of sovereignty and self-determination, which paved the way for secession from the Yugoslav federation. As a result, everyone held their breath when, in September 1991, the weak Republic of Macedonia, unarmed and populated by only 1.3 million ethnic Macedonians (and, among others, half a million Albanians), declared independence and entered in the open arena of Balkan's policies [1].

Macedonia (North Macedonia) made its self-determination without war, seceding from Yugoslavia, but later became an arena of inter-ethnic clashes within its territory, who had lived together in the same region. Interethnic Macedonia (North Macedonia) was established as an independent state and separated from the Yugoslav federation.

But, Macedonia (North Macedonia) after some time became an arena of clashes for its ethnicity, in 2001 Macedonia (North Macedonia) suffered a severe blow, where a period of the fighting took place within it between Albanians and Macedonians. This clash within Macedonia (North Macedonia) was concluded with the international community's help, where through the "Ohrid Agreement" they managed to reduce the tension. This agreement aims to resolve Macedonia's problems (North Macedonia), which have arisen since its independence declaration. This agreement opens a 
new phase for Macedonia (North Macedonia) and constitutes a geopolitical goal influenced by international factors. Macedonia (North Macedonia) is also used as a buffer state between Albanians and Serbs.

Macedonia (North Macedonia) has achieved progress, and democratic reforms are NATO members and are candidates for EU membership. He solved the name problem he had with Greece by moving it from Macedonia to North Macedonia. The situation between the ethnicities is calm. However, there are many things to do, to achieve higher stability.

Bosnia and Herzegovina. Bosnia and Herzegovina was the bloodiest arena of the former Yugoslavia, many domestic, and international factors made bloody hands in this country. Along ethnic war took place in this country with catastrophic consequences. In 1991, while trying to negotiate an end to the Slovenian war for independence, EU President Jacque Poos declared that "the hour of Europe has dawned." It turned out to be a long and dark hour in Bosnia, as the Europeans were not prepared to intervene militarily, and the Americans were focused elsewhere [9].

The international factor neglected Bosnia and Herzegovina's issue, left it slipping into an arena of ethnic cleansing. The most bloody and challenging road in the former Yugoslavia was that of Bosnia and Herzegovina. The components that influenced this region were ethnic, religious, political, administrative, military.

Initiatives like the Owen/Stoltenberg and Vance/Owen plans, which in many respects foreshadowed the eventual power-sharing settlement reached Dayton.

Not only failed to bring about an end to the war but likely caused ethnic cleansing by identifying parts of the country that would be designated "Croat," "Serb," and "Bosniak" [10]. Thus, the international community got into a long stalemate, which brought significant consequences for Bosnia and Herzegovina.

Bosnia went through a terrible conflict which left significant scars. Within it, Bosnia is a separate "creature", a body that functioned in several parts. The interests and influences towards this country, especially the Russian ones, cause instability continuously. It can be concluded that the Bosnian issue is a solution without a solution, but it is probably the best possible solution in cases where the impossible solution goes around.
Now Bosnia is economically relatively well developed, taking into account the underground wealth etc. This country is not a member of NATO and is not a member of the EU.

Ethnic and religious problems come to the fore within this state. Multiethnic Bosnia after the breakup of the former Yugoslavia is a permanent long-term threat in the Balkans for many reasons, including ethnic, religious, and Russian and Serbian influences. Bosnia has undergone major geopolitical configurations since the Yugoslav federation's disintegration. Still, significant changes may emerge later from this very country, a "three-legged creature" extending into the Balkans.

Kosovo. Kosovo is a region with particular geostrategic importance and can be said to be the heart of the Balkans' geopolitics. For this, Serbia has consistently insisted on Kosovo. Through Kosovo, Serbia is favoured and gains a position where the geopolitical interests of the powers of the European Continent and other powers outside this continent are intertwined.

From Nachertania (1844) to Patkoi (1999), the Serbs' goals have always been the same: exterminating the Kosovo Albanians. "Naçertanje" is the platform of Ilija Garashani created based on the sacred Serbian Doctrine. "Naçertanje" was explicitly based on the program of extermination and expulsion of Albanians by force according to foreign international opinion's reactions. This select war platform served as the curriculum of Pasic, King Nikola (Krajl Nikolla), Qubrillovic, Andric, Rankovic, Mugosa, Tempo, Jovic, Trajkovic, Milosevic [7]. The beginnings of "Nachertanja" are part of the tremendous Slavic programs of Russia, which have found their way and found implementation in the subsequent periods of the Serbian regimes, until today, with one main goal: access to warm seas through the disappearance and displacement of Albanians [2]. Through various platforms and plans, Serbian policies and actions have been against the existence of Kosovo. Geopolitically, Serbia has followed the Russian geopolitical school of Pan-Slavism towards Kosovo.

Kosovo was the most impoverished and most oppressed country during the Yugoslav period. The first steps for the end of the former Yugoslavia started right from Kosovo. With the Constitution of 1974, Kosovo became an autonomous province. Since then, Kosovo's course changed its course and moved towards its final status, which would later allude to Kosovo's independence. 
The people of Kosovo's efforts to create an independent state date back a long time, but they took on a political organisation and other forms mainly from the late 1980 and early 1990 when the former's breakup Yugoslavia began. The years 19881989 date back to Albanians' mass protests against Serbia's policies that were repressive of Kosovo, resulting in Slobodan Milosevic's removal of Kosovo's autonomy, which returned Kosovo as part of Serbia [11]. The disintegration of this creature [Yugoslavia] resulted in new geopolitical realities, changed geographical maps of this geospace, new states were born and influenced the international community's awareness. The Albanian people mainly constituted that creature that was unjustly separated from his trunk and held violently in that creature with nothing in the standard [6].

Kosovo's secession from the Yugoslav federation was accompanied by war and serious crimes committed by Serbian repression of the innocent population. Terror and ethnic cleansing were exercised on the innocent people of Kosovo. This situation led to the international community's intervention, which had learned the necessary lessons from the earlier events of the separation of other states from the former Yugoslavia.

Serbia's nationalist, political and geopolitical views failed. Kosovo declared its independence in 2008, becoming an independent state and internationally recognised. With Kosovo's independence, the centuries-old sufferings and horrors that Kosovo's people have gone through are resolved.

Kosovo is not yet a member of NATO and is not a member of the EU. Well, this country continues to work with will and commitment for NATO and EU membership. There are no easy solutions to the problems in Kosovo. However, some ways provide great potential for inclusion, peace, stability and development [12].

An extensive geopolitical configuration has taken place in the Balkans in the case of Kosovo. Kosovo enjoys a tremendous geopolitical and geostrategic position and importance in the Balkans; it wants this by nature and must use it legally as a resource for its goals and interests at all levels. Thus, Kosovo constitutes a new geopolitical configuration and environment in the Balkans.

Serbia. It can be called the heart of the former Yugoslavia, but this country with its nationalism was the leading cause of the wars in the former Yugoslavia. In 1992, the two republics of Montenegro and Serbia merged, becoming the Federal Republic of Yugoslavia, and later in 2002, an agreement was signed to form Serbia's state Montenegro. Through the popular referendum of 2006, Montenegro declared independence as a single and sovereign state.

Serbia inherited a mountain of problems from Milosevic's ominous policies. Serbia is considered the biggest loser in the Yugoslav crisis. Milosevic's policies sent Serbia catastrophic, putting it in difficult psychological, nationalist and economic situations.

Serbia's geopolitical orientations and plans in the Balkans failed with Slovenia, Croatia, Macedonia, Bosnia and Herzegovina, Kosovo, Montenegro. These states' independence caused Serbia's geopolitics to experience a collapse, precisely with this geopolitical configuration ended the idea of "Greater Serbia", which the Serbs had dreamed of for centuries and Milosevic thought to make a reality during the 90s. Serbia had followed in a straight line the Russian geopolitical school which supports Pan-Slavism. The geopolitical Doctrine of Pan-Slavism was created in the 19th century by a Russian general named Ignatiev; this Doctrine served as a reference for the Russian Tsars to apply the Russian Doctrine of progress from East to West. Slavic countries (Serbia) have had strong support from Russian policy to extend its hegemony in the Balkan region. Russian politics and geopolitics have continuously influenced Serbia. Precisely the Doctrine of Pan-Slavism has had a significant impact on Serbia, which directly affects the harm of the Albanian people by Serbia.

Serbia still faces problems within the country as well as democratic reforms. This country continues to pursue traditional politics to the West as well as Russia. Serbia has the biggest problem with the state of Kosovo and its issue. The issues for the state of Serbia still lie essentially in terms of its orientation.

Serbia is not a member of NATO, not is it a member of the EU. The Serbian state is still trying in the new political and geopolitical configuration, aiming to realise the old desires, stopping it in its development and progress towards growth and membership in NATO, EU, and cooperation with Western partners.

Montenegro. With the secession of the state union (Union) Serbia-Montenegro, in 2006 Montenegro became an independent and democratic state known as the Republic of Montenegro. Many 
ethnic groups live in Montenegro, Albanians, Serbs, Bosniaks, Roma, etc. Montenegro has a small territory and access to the sea.

Serbia has continuously put pressure on Montenegro regarding its approach, especially to the Republic of Kosovo. Montenegro has been geopolitically influenced and pressured by Russia. Usually, the Russian focus is on small and fragile states; the Russian strategy relies mainly on ethnic Serb factors, the Serbian church, and pro-Russian leaders and political actors.

Montenegro, as a small country, has tremendous geostrategic importance. But this country can't only face the malicious interests and influences of the Podgorica-Belgrade-Moscow triangle, so it must continue to have the help and support of the EU, NATO and the US.

Montenegro has good relations with all its neighbours. After Yugoslavia's breakup, the geopolitical and geostrategic configurations have prompted Montenegro to make progress and increase the security factor in the region, especially with NATO membership. The latter's NATO membership closes Russia's path to penetration within the Western Balkans region via Montenegro. Montenegro is a member of NATO but not a member of the EU. The advancements and prosperity that this country is making directly affect the development and progress in security, stability and geopolitics throughout the Western Balkans region.

\section{Kosovo Independence; stability and security consolidation}

After a long journey filled with suffering and oppression from Serbia, Kosovo declared independence on February 17, 2008. It was recognised by the most powerful countries in the world which have political and diplomatic experience. Kosovo's independence was a geopolitical and geostrategic configuration for the Western Balkans in general, orienting it towards a new reality of stability and security for the region.

After long and harsh Balkan wars of the ' 90 - is, the world diplomacy was thinking one thing: Balkan security. Except for ethnic divisions, not a small role played the religious differences between Croats and Serbs, Moslem, Catholic and Orthodox Bosnian, Kosovar Albanians, Kosovar Serbs, and Slavs Macedonian and Albanians [3]. The peoples of the Balkans face a significant challenge in living together. But it can rightly be concluded that the ethnic problems were much deeper than the religious ones. Ethnic issues were crucial in Kosovo's case, which has consistently faced Serbia precisely with the ethnic issue as the primary point and problem. Disputes between Kosovo Albanians and Serbs have a long history. Serbia has always pursued anti-Albanian doctrines and policies with extermination intentions. From Nachertania (1844) to the Patkoi plan (1999), Serbia had preferences for the Albanians' extermination and destruction.

But is it likely that the Western Balkans will be peaceful and that different ethnicities, the Slaves and the Albanians, will live together? The answer is yes! But, the presence of a third party, international, is needed to approximate situation. Albanians can be said to be much more acceptable in terms of living with other ethnicities. Albanians have shown to live in a common state with the Slavs and even establish standard policies. The case which proves this is Macedonia. On 2001, these two ethnic groups clashed militarily, but still made the historic compromise with the Ohrid Agreement framework [3].

Kosovo Albanians have proven to the world that they can live together with different ethnic groups in lasting security and stability. Kosovo demonstrates with respect and tolerance towards minorities, mainly Serbs, and the multiethnic state. As a distinction from the Serbs, the state's establishment has not based the religion but Albanians' language. This because Albanians are multi-confessional - Muslim, Orthodox and Catholic [4].

The problematic past between Kosovo and Serbia make it difficult for Serbia to accept Kosovo's independence. Also, Russia's destructive role for its geopolitical and geostrategic interests in the face of Kosovo's independence is a challenge and an impact, both internally and externally.

Kosovo's independence and international support have brought stability to the region. The USA and the EU's geopolitical and geostrategic influences have also made Kosovo have strength, functionality, and stability for the future, creating a stable and tolerant state. So, Kosovo's independence is stability for the country and the region; it is also a consolidation of general security.

\section{CONCLUSION}

The disintegration of the former Yugoslavia constitutes the Western Balkans' geopolitical 
configuration, bringing stability and development to the region.

The disintegration, changes and configurations in the former Yugoslavia territory came for many reasons: political, historical, economic, military, geopolitical and geostrategic.

The tremendous geopolitical interests of the great powers constitute a challenging knot for this region. The disintegration of the former Yugoslavia was marked by conflicts and clashes between different ethnic groups within the territory. The international factor also played a vital role in the issue of this region and these conflicts.

The Albanian factor in the Balkans plays a colossal role were without the rights and stability of these people; there can never be peace in this region. The Albanian factor's position is the continuous developments in the Western Balkans, especially the former Yugoslavia's disintegration. Albanians are divided people in many Balkan countries which has a crucial impact on stability and security. Kosovo's independence in this region is a fair and adequate solution for Kosovo itself and the area. Kosovo's independence produced a new flow of developments in the Balkan region. However, Serbia did not welcome it, but which did not have such a significant impact on preventing this development. Kosovo was recognised and supported by the most powerful and largest countries in the world. Kosovo is also expected to integrate into Euro-Atlantic structures. Kosovo has proven that it can live together with different ethnicities within the state, respecting minorities and being tolerant.

We can conclude that cooperation between the Balkan countries is crucial for the region's integration and development. The Balkan countries must think like a democratic and open leader for the sake of peace and stability, first for themselves and then for the area in which they belong. The lessons learned from the past should serve the countries of this region as a lesson towards a common and peaceful future.

\section{REFERENCES}

1. Ahrens, G.-H. (2007). Diplomacy on the Edge. Washington: Woodrow Wilson Centre Press.

2. Ballshi, A. (2002). VËSHTRIM MBI LIBRIN: «SEKRETI I SUNDIMIT TË BOTËS». Retrieved from https://pashtriku.beepworld.de/files/komplotiboteror/veshtrimperlibrinsekrete...htm

3. Buzan, B., \& Waever, O. (2003). Regions and powers; the structure of international security. Cambridge: Cambridge University Press.

4. Clayer, N. (2012). Në fillimet e nacionalizmit shqiptar. Tiranë: Përpjekja.

5. Dugin, A. (2015). Last War of the World-Island. The Geopolitics of Contemporary Russia. London: Arktos.

6. Ferati, H. (2013). Gjeopolitika dhe Gjeostrategjia (teoria dhe praktika). Prishtinë: ILAR.

7. Fischer, W. (1953). Self-representation of the Serbian "Civil-Classen" in the 19 Century. Retrieved from http://www.kakanien-revisited.at/beitr/emerg/wfischer1.pdf

8. Garde, P. (1992). Vie et mort de la Yougoslavie. Paris: Fayard.

9. Glaurdić, J. (2011). The Hour of Europe: Western Powers and the Breakup of Yugoslavia. New Haven: Yale University Press.

10. Klemencic, M. (2009). The international community and the FRY / Belligerents, 1989-1997. Retrieved from https://www.researchgate.net/publication/286979507_The_international_community_and_the _FRY_Belligerents_1989-1997

11. Mekaj, G. (2020). Kosovo during 1989-1999. The Baltic Scientific Journals, 8(1), 37-42.

12. Mekaj, G., \& Aliaj, K. (2019). Ethnic Dimension in Kosovo, Security and its Consequences in Transition. ILIRIA International Review, 9(1), 160-177.

13. Sullivan, K. L. (2012). Slobodan Milosevic's Yugoslavia. Minneapolis: Lerner Publishing Group. 
14. Teokarević, J. (2014, November 27). The fall of the Berlin Wall and post-Yugoslav transition.

Retrieved from https://biepag.eu/the-fall-of-the-berlin-wall-and-post-yugoslav-transition/ 